\title{
$\mathrm{C} 2 \mathrm{C} 12$ 근육세포의 산화적 손상에 대한 홍경천-홍삼 추출물 혼합액 발효물의 보호효과
}

\author{
윤보라 · 김영현 · 이종석 · 홍희도 ${ }^{*}$ - 이영경 ${ }^{*}$ · 조장원 ${ }^{*}$ · 김영찬 ${ }^{*}{ }^{\dagger}$ 이옥환
}

강원대학교 식품생명공학과, "한국식품연구원

\section{Protective Effect of Ferments of Hot-water Extract Mixture from Rhodiola sachalinensis and Red Ginseng on Oxidative Stress-induced C2C12 Myoblast}

\author{
Bo-Ra Yoon, Young-Hyun Kim, Jong-Seok Lee, Hee-Do Hong*, Young-Kyoung Rhee*, \\ Chang-Won Cho*, Young-Chan $\mathrm{Kim}^{*}$ and ${ }^{\dagger}$ Ok-Hwan Lee \\ Dept. of Food Science and Biotechnology, Kangwon National University, Chuncheon 200-701, Korea \\ *Korea Food Research Institute, Seongnam 463-746, Korea
}

\begin{abstract}
Rhodiola spp. and red ginseng have been used for food and medicinal applications in disease chemoprevention in many Asian countries. Increased oxidative stress by reactive oxygen species (ROS) has been proposed to be a major cause of muscle fatigue. The present study was designed to investigate the protective effects of a fermented hot-water extract mixture from Rhodiola sachalinensis and red ginseng (MFR) on cell damage and the antioxidant enzyme system in $\mathrm{H}_{2} \mathrm{O}_{2}$-induced oxidative stress in skeletal muscle cells. $\mathrm{C} 2 \mathrm{C} 12$ myoblasts were treated with various concentrations of NFR (non-fermented Rhodiola sachalinensis extract), FR (fermented hot-water extract from Rhodiola sachalinensis) and MFR for up to 5 days after the standard induction of differentiation, followed by semi-quantitative RT-PCR. MFR treatment dose-dependently protected oxidative damage of $\mathrm{C} 2 \mathrm{C} 12$ cells. The treatment with MFR also enhanced mRNA expressions of MyoD, Cu/Zn SOD, Mn-SOD and GPX up to $16 \%$. These results indicate that MFR exerts an anti-oxidative effect through a mechanism (s) that may involve the up-regulation of antioxidant enzymes, which may be important for the cellular redox environment in muscle cells.
\end{abstract}

Key words: C2C12 myoblast, Rhodiola sachalinensis, red ginseng, fermentation, oxidative stress

\section{서 론}

활성산소종(reactive oxygen species, ROS)은 산소의 환원 대사산물로서, 스트레스, 과식, 음주, 흡연, 방사선, 초음파 및 환경오염, 세포 내 대사과정의 불균형 등의 요인으로 인해 체 내 산화-환원 대사의 균형이 깨어져 야기되는 것으로 알려져 있다(Alessio HM 1993; David 등 1993; Jenkins RR 1993). 과잉 으로 생성된 활성산소종은 세포 내 DNA 및 단백질의 심한 손
상을 일으켜, 노화, 세포의 돌연변이, 뇌질환, 심장질환, 동맥 경화 등의 여러 질환이 발병하는 것으로 알려져 있다(Stadman \& Berlett 1998; Yun JH 2010; Seo \& Kim 2012). 특히, 근육조 직에서는 superoxide radical anion 또는 hydrogen peroxide 등 의 산소분자가 불완전하게 환원되면 강력한 산화제가 되어 근육 내 피로감을 야기시키기 때문에(Halliwell B 1989), 체 내 산화적 스트레스를 저감하는 천연물 유래 기능성 식품을 개발하기 위하여 다양한 세포주 모델이 이용되고 있다. 근

\footnotetext{
${ }^{\dagger}$ Corresponding author: Ok-Hwan Lee, Dept. of Food Science and Biotechnology, Kangwon National University, Chuncheon 200-701, Korea. Tel: +82-33-250-6454, Fax: +82-33-259-5565, E-mail: loh99@kangwon.ac.kr
} 
육세포주로 널리 알려진 $\mathrm{C} 2 \mathrm{C} 12$ myoblast는 근육으로 분화되 기 전단계의 세포로서, 여러 가지 호르몬이나 외부자극에 의 해 다핵의 myotube로의 형태적인 분화로 특정지어진다(Kim \& Lee 2007). 과격한 운동에 의한 골격근 손상이나, 노화에 의한 골격근 질환 등 임상적으로 골격근의 장애에서 나타나 는 여러 증상 중 일부분은 골격근의 세포 손상과 연관되어 있다고 보고되고 있다(Jennifer 등 2001; Dirks \& Leeuwenburgh 2002). 최근 이러한 골격근 세포 손상의 주요한 기전으로 산 화성 스트레스에 의한 손상이 설득력 있게 받아들여지고 있 으며, 과격한 운동이나 노화에 의해 생성된 자유라디칼이 세 포 손상을 유발한다고 알려져 있다(Jackson \& O'Farrell 1993; Stangel 등 1996).

한편, 천연물에 존재하는 항산화 성분들에 의한 근육세포 내 산화적 손상 억제와 근육조직의 피로 저감화에 관한 연구 가 시도된 바 있다. 천연물 유래 항산화 소재 중, 홍경천은 동북아, 중앙아시아, 북미, 북유럽의 고산지대에서 자라는 다 년생 초본 식물로, 뿌리와 줄기를 약용으로 사용하고 있고, 유럽과 아시아에서는 신경계통의 자극, 우울증의 감소, 작업 능력의 향상, 피로 회복, 고산병의 예방 등의 효능을 가진 전 통약물로 알려져 있다(Lee YN 1997; Kelly GS 2001; Oh 등 2010). 홍경천의 각종 화학적, 생물학적 및 신체적 스트레스 인자들에 대한 저항력의 증강 효능을 연구한 결과, 홍경천을 다양한 생리기능의 변화에 대하여 유효한 효능을 발휘하는 고려인삼이나 가시오가피와 같은 adaptogen의 일종으로 설명 하고 있다(Fulder SJ 1981; Ryu 등 2008). 최근에는 홍경천의 항산화 효능(Kanupriya 등 2005), 신경세포 손상 보호(Mook 등 2002) 등 다양한 효능이 보고된 바 있고, 주요 성분으로 salidroside 및 tyrosol이 알려져 있다.

또한, 고려인삼(Panax ginseng C. A. Mayer)의 인삼가공품 (수삼, 백삼, 홍삼 등)은 수천 년 동안 피로 회복 및 면역력 증강제로 이용되어 왔고, 주요한 생리활성 물질로 ginsenosides, polyacetylenes, 산성다당체, 인삼단백질, 페놀성 화합물 등이 널리 알려져 있다(Hyun 등 2009). 피로 회복 및 운동능력 향 상 등의 효능을 갖는 홍삼과 홍경천의 단독 또는 복합처리에 의한 근육세포 내 산화적 스트레스 저감 연구는 아직 체계적 으로 이루어지지 않고 있다. 또한, 홍경천의 건강기능식품 소 재화를 위한 관심도가 점차 증가하고 있는 시점에서 홍경천 추출물, 홍경천 추출액 발효물, 홍경천-홍삼 추출물 혼합액 발효물 등에 대한 연구는 향후 건강기능식품 소재화를 위한 기초자료로서 매우 중요하며, 이에 대한 연구가 필요한 실정 이다.

따라서, 본 연구에서는 근육세포주로 잘 알려진 $\mathrm{C} 2 \mathrm{C} 12$ myoblast 세포를 이용하여 근육세포 분화과정 동안 $\mathrm{H}_{2} \mathrm{O}_{2}$ 로 산화적 손상을 유도하면서 홍경천 추출물, 홍경천 추출액 발
효물, 홍경천-홍삼 추출물 혼합액 발효물을 처리하여 근육세 포의 morphology, cell viability 및 $\mathrm{Cu} / \mathrm{Zn} \mathrm{SOD}, \mathrm{GPx}$ 항산화 효 소의 발현 양상을 비교하여 홍경천-홍삼 추출물 혼합액 발효 물의 근육세포 보호 효과를 통한 산화적 손상 억제 효능을 평가하였다.

\section{재료 및 방법}

\section{1. 실험 재료}

본 연구에 사용된 시료는 홍경천 추출물(non-fermented Rhodiola sachalinensis, NFR), 홍경천 추출액 발효물(fermented hot-water extract from Rhodiola sachalinensis, FR) 및 홍경천홍삼 추출물 혼합액 발효물(fermented hot-water extract mixture from Rhodiola sachalinensis and red ginseng, MFR)로 Sung 등 (2012)의 방법에 따라 제조하였다. 홍경천 및 홍삼 분말을 각 각 $100 \mathrm{~g}$ 씩 추출용기에 취한 후, 증류수 $1 \ell$ 를 가하여 $90^{\circ} \mathrm{C}$ 에 서 3 시간 동안 추출하여 상온에서 냉각시키고, 원심분리기 (Mega 17R, Hanil Science Industrial Co. Ltd., Gyonggi-do, Korea) 를 이용하여 $6,500 \times \mathrm{g}$ 에서 20 분간 원심분리하여 얻은 상등액 을 홍경천 및 홍삼 추출물로 하여 발효에 이용하였다. 홍경천 단독 추출물 및 홍경천-홍삼 복합 추출물을 고압멸균기 (Mega Science Co., MG-6845, Gyonggi-do, Korea)로 $121{ }^{\circ} \mathrm{C}$, 15 분간 멸균한 후 활성화된 유산균(Lactobacillus acidophillus 및 Bifidobacterium longum $)$ 을 $1 \%\left(1.0 \times 10^{6} \mathrm{CFU} / \mathrm{m} \ell\right)$ 접종한 다 음 $37^{\circ} \mathrm{C}$ 에서 24 48시간 동안 배양하였다. 예비실험을 통하 여 홍경천과 홍삼 추출액의 혼합비율은 $6: 4(\mathrm{w} / \mathrm{w})$ 로 결정하 여 발효를 진행하였다. 발효 종료 후 $101{ }^{\circ} \mathrm{C}$ 에서 10 분간 살균 과정을 거친 발효액은 여과하여 농축한 후 동결건조기(Tokoyo Rikakikai Co. Ltd., FD-1000, Tokyo, Japan)를 이용하여 분말화 하였다.

NFR, FR 및 MFR을 시료로 하여 PBS(phosphate buffered saline)에 녹인 후, $\mathrm{C} 2 \mathrm{C} 12$ 세포독성 및 근육세포 분화 실험에 사용하였다. $\mathrm{C} 2 \mathrm{C} 12$ 세포배양에 사용된 Dulbecco's modified Eagle's medium(DMEM), horse serum(HS), fetal bovine serum(FBS), penicillin-streptomycin(P/S), PBS 및 trypsin-EDTA는 Gibco(Gaithersburg, MD, USA)로부터 구입하여 사용하였다.

\section{2. $\mathrm{C} 2 \mathrm{C} 12$ 세포 배양 및 분화}

$\mathrm{C} 2 \mathrm{C} 12$ 근육세포 분화과정 중, 시료에 의한 세포의 손상 정 도를 관찰하였다. 마우스 유래 $\mathrm{C} 2 \mathrm{C} 12$ 세포주는 American Type Culture Collection(ATCC, CRL-1772, Manassas, VA, USA)으로 부터 분양 받아 사용하였다. $\mathrm{C} 2 \mathrm{C} 12$ 근육세포는 실험목적에 따라 $60 \mathrm{~mm}$ petridish에 각각 $1 \times 10^{6}$ 의 seeding한 후, $\mathrm{FBS}(10 \%)$ 및 $\mathrm{P} / \mathrm{S}(1 \%)$ 를 함유한 고농도 포도당 $\mathrm{DMEM}(89 \%)$ 에서 $80 \%$ 
confluence 될 때까지 배양하였다. 그 후 $\mathrm{HS}(2 \%)$ 로 근육세포 의 분화를 유도하였다(Yoon 등 2012). 근육세포 분화(day 0) 시 $\mathrm{DMEM}$ 에 $\mathrm{H}_{2} \mathrm{O}_{2} 1 \mathrm{mM}$ 과 시료를 각각 100, 250 및 $500 \mu \mathrm{g} /$ $\mathrm{m} \ell$ 로 처리하여 $\mathrm{H}_{2} \mathrm{O}_{2}$ 에 의한 산화적 손상 억제 효과를 관찰하 였다. 근육세포의 분화는 2 일마다 지속적으로 $2 \% \mathrm{HS}$ 가 함유 된 배지에 $\mathrm{H}_{2} \mathrm{O}_{2}$ 와 각각의 시료를 처리한 후, 5 일 동안 분화시 키면서 현미경을 통해 morphology를 관찰하였다.

\section{MTT Assay를 이용한 홍경천 시료의 세포독성평가}

$\mathrm{C} 2 \mathrm{C} 12$ 에 대한 시료의 세포 생존능 평가는 MTT(thiazoly blue tetrazolium bromid)를 이용하여 측정하였다. 즉, $\mathrm{C} 2 \mathrm{C} 12$ 세 포는 실험 전날 $1 \times 10^{6}$ cells $/ \mathrm{m} \ell$ 농도로 96-well plate에 seeding 하고, 시료 100,250 및 $500 \mu \mathrm{g} / \mathrm{m} \ell$ 를 처리하여 24시간 동안 배 양하였다. 그 후 $4{ }^{\circ} \mathrm{C}$ 에 보관 중인 MTT를 $5 \mathrm{mg} / \mathrm{ml}$ 의 농도로 PBS에 녹인 다음 syringe를 이용하여 여과하고, pipet을 이용 하여 96-well medium 부피의 $20 \%$ 되는 양 만큼 취하여 각각 의 well에 조심스럽게 첨가하여 plate를 바닥에 붙인 상태로 전후좌우로 가볍게 흔들면서 혼합하였다. $\mathrm{CO}_{2}$ incubator에서 5 시간 동안 배양한 후 배양액을 제거하고, DMSO $200 \mu l$ 를 첨가하여 formazan을 용출시킨 뒤 $\mathrm{CO}_{2}$ incubator에서 30 분 동 안 배양하였다. 30 분 후 용출된 용액을 새 96-well plate로 옮겨 $\mathrm{ELISA}$ 를 이용하여 $550 \mathrm{~nm}$ 흡광도 값에서 $650 \mathrm{~nm}$ 의 흡광도 값 을 뺀 결과 값으로 세포 생존능을 계산하였다.

\section{4. 유전자 발현 조사}

근육세포 분화 및 항산화 효소의 유전자 발현 향상을 조사 하기 위하여 세포에 존재하는 total RNA를 추출한 후, 역전사 중합효소(reverse transcriptase)를 사용하여 cDNA를 만들었다. 합성된 $\mathrm{cDNA}$ 와 각각의 유전자별 primer를 RT-PCR로 증폭한 후 유전자의 발현 정도를 측정하였다. 근육세포로부터 total RNA의 추출은 TRIzol reagent(phenol + guanidine isothiocyanate) 방법을 이용하였다. 분화 5일째 되는 근육세포에 $\mathrm{PBS}$ 를 이용 하여 2회 세척하고, $1 \mathrm{~m} \ell$ 의 Trizol을 첨가하여 세포들을 수확 하였다. $1 \mathrm{ml}$ 의 TRIzol reagent당 $0.2 \mathrm{ml}$ 의 chloroform을 넣고 15 초간 잘 흔들어 준 후 실온에서 2 3분간 반응시키고, 15,000 $\mathrm{rpm}$ 에서 10 분간 원심분리한 후 상등액을 걷어내어 다른 튜브

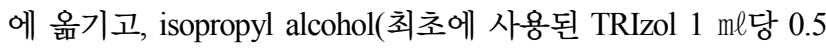
$\mathrm{m} \ell)$ 을 넣고 10 분간 반응시켜 $\mathrm{RNA}$ 를 침전시켰다. 침전된 RNA에 75\% DEPC-ethanol로 씻어준 후(최초에 사용된 TRIzol $1 \mathrm{~m} \ell$ 당 $1 \mathrm{m \ell}$ ) 11,000 rpm에서 약 5분간 원심분리하고 실온에 서 pellet을 5 10분간 건조시킨 다음 DEPC water $40 \mu \ell$ 에 녹여 서 spectrophotometer $(260 \mathrm{~nm})$ 로 흡광도를 측정하여 total RNA 의 농도를 정량하였다. cDNA Premix(Maxime RT Premix (oligo $\mathrm{dT}$ primer), Seongnam, South Korea)에 동일한 농도의 total $\mathrm{RNA}$ 를 각각 $5 \mu \mathrm{g}$ 씩 넣고 전체 용량이 $20 \mu$ 가 되도록 DEPCwater를 첨가한 후, $45^{\circ} \mathrm{C}$ 에서 60 분간, $95^{\circ} \mathrm{C}$ 에서 5 분간 처리하 여 $\mathrm{cDNA}$ 를 합성하였다. $\mathrm{cDNA}$ 와 근육세포 분화와 관련된 주 요 유전자(Table 1)의 primer들을 각각 혼합한 후, RT-PCR Amplification mixture를 혼합하여 total volume이 $20 \mu \ell$ 가 되도 록 하여, denaturation, annealing, polymerization 단계를 35회 반복하면서 원하는 DNA 부분을 증폭하였다. 이때 annealing 온도는 primer에 따라 각각 적정온도로 처리하였다. RT-PCR 산물을 확인하기 위하여 $5 \mu l$ 를 취하여 $1.5 \%$ 한천(agarose) gel에서 전기영동한 후, $\mathrm{EtBr}$ (ethidiumbromide)로 염색하여 자 외선투시기(transilluminator; Biorad, Seoul, Korea)를 이용하여 증폭된 DNA band를 확인하였다. DNA band는 image J program 을 이용하여 band intensity로 수치화하여 나타내었다.

\section{5. 통계분석}

모든 실험 결과는 SAS package(release 8.01)를 이용하여 one-way ANOVA 분석 수행하였고, 평균값의 통계적 유의성 은 $p<0.05$ 수준에서 검정하였다.

\section{결과 및 고찰}

\section{1. 산화적 스트레스에 의한 $\mathrm{C} 2 \mathrm{C} 12$ 의 형태학적 변화}

$\mathrm{H}_{2} \mathrm{O}_{2}$ 에 의해 유도된 산화적 스트레스로 인한 $\mathrm{C} 2 \mathrm{C} 12$ 근육 세포 형태학적 변화 및 세포독성을 평가하고자 $\mathrm{H}_{2} \mathrm{O}_{2}$ 를 50 , $100,500,1,000 \mu \mathrm{M}$ 의 농도범위로 처리하여 세포에 MTT assay 를 실시한 결과(Fig. 1), $500 \mu \mathrm{m}$ 까지는 대조군(Control)과의 유

Table 1. Primer sequences for semi-quantitative RT-PCR analysis

\begin{tabular}{lcc}
\hline \multicolumn{1}{c}{ Primers } & \multicolumn{2}{c}{ Sequences } \\
\cline { 2 - 3 } Myo D & Forward & Reverse \\
Cu/Zn-SOD & TACCCAAGGTGGAGACCTTCCTG & GACTCTGAGTCGCCACTGTA \\
Mn-SOD & CAGCATGGGTTCCACGTCCA & CACATTGGCCACACCGTCCT \\
GPx(glutathione peroxidase) & GGGTTGGCTTGGTTTCAATAAGGAA & AGGTAGTAAGCGTGCTCCCACACAT \\
GAPDH & CTCGGTTTCCCGTGCAATCAG & GTGCAGCCAGTAATCACCAAG \\
\hline
\end{tabular}




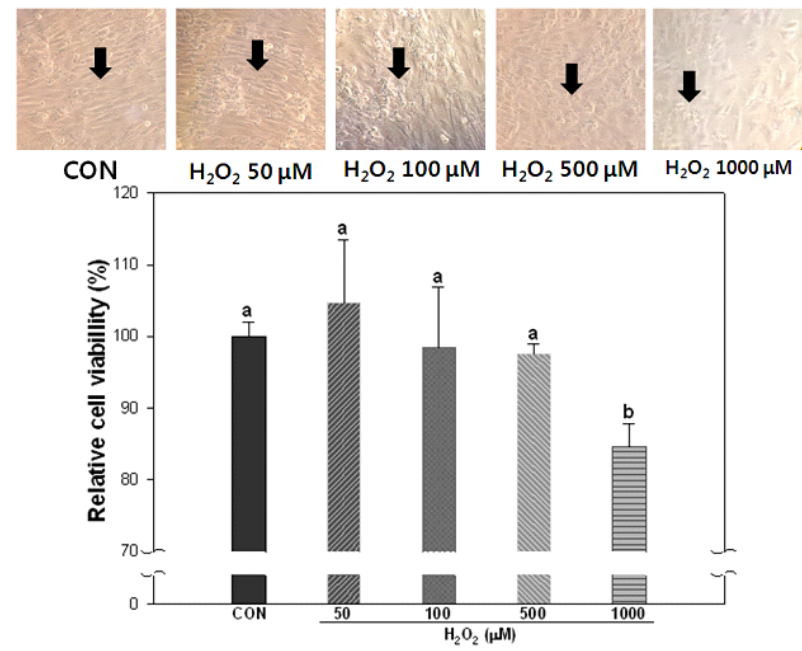

Fig. 1. Cytotoxicity of hydrogen peroxide $\left(\mathrm{H}_{2} \mathrm{O}_{2}\right)$ on cell viability of C2C12 myoblast. Cell viability was measured by MTT assay. The exponentially growing cells were plated into 96-well micro plates at a density of $1 \times 10^{6}$ cells/well in DMEM/FBS medium and incubated for $24 \mathrm{~h}$ prior to treatment at $37^{\circ} \mathrm{C}$ in $5 \% \mathrm{CO}_{2}$. Cells were divided into a control group and a $\mathrm{H}_{2} \mathrm{O}_{2}$ group at concentration indicated. Each value is the mean \pm standard deviation of the results from six different plates $(n=6)$ and is representative of results from at least two different experiments. Statistical analysis was performed using the one-way $\operatorname{ANOVA}(p<0.05)$

의차를 거의 보이지 않았으나, $1,000 \mu l$ 의 농도에서는 세포의 형태학적 변화 및 세포독성이 관찰되었다 $(p<0.05)$. 따라서 근 육세포의 분화 중 세포 내 산화적 스트레스의 야기를 위한 $\mathrm{H}_{2} \mathrm{O}_{2}$ 의 적정 처리농도는 $1,000 \mu \mathrm{M}$ (이하 $1 \mathrm{mM}$ )로 결정하여 실험하였으며, 이는 Yoon 등(2012)의 산화적 스트레스에 대 한 고온고압처리 인삼의 억제 효과를 연구한 논문에서 $\mathrm{C} 2 \mathrm{C} 12$ 근육세포에 처리하는 $\mathrm{H}_{2} \mathrm{O}_{2}$ 의 농도를 $1 \mathrm{mM}$ 로 설정한 것과 같 은 결과를 보인 것이다.

\section{2. 홍경천-홍삼 추출물 혼합액 발효물의 산화적 손상 억 제효과}

근육세포에 $\mathrm{H}_{2} \mathrm{O}_{2} 1 \mathrm{mM}$ 로 산화적 스트레스를 가한 뒤, 대 표적인 항산화제로 알려진 N-acetyl cysteine(NAC, $1 \mathrm{mM}$ ), 홍 경천 추출물(NFR), 홍경천 발효물(FR) 및 홍경천-홍삼 복합 발효물(MFR)을 처리하여 근육세포의 형태학적인 변화 및 cell viability를 평가한 결과는 Fig. 2 5와 같다. 먼저, NAC에 대한 산화적 손상 억제 효과를 평가한 결과(Fig. 2), $\mathrm{H}_{2} \mathrm{O}_{2}$ 에 의해 산화적 손상이 유도된 근육세포에 비해 형태학적으로 산화적 손상이 억제되는 것으로 나타났다. MTT assay에 의한
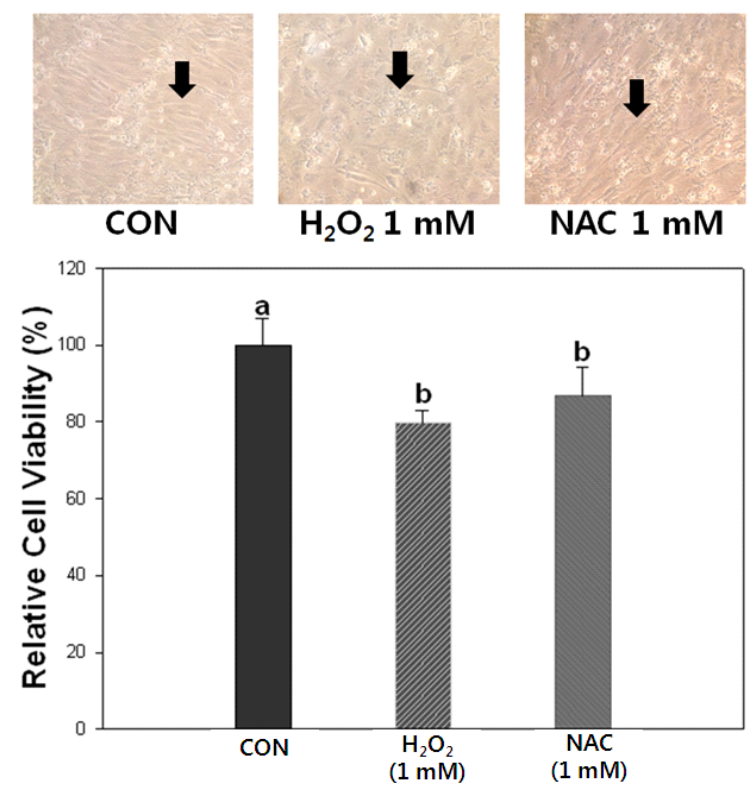

Fig. 2 Protective effect of $\mathrm{N}$-acetyl cysteine(NAC) on cell viability of oxidative stress-induced $\mathrm{C} 2 \mathrm{C} 12$ myoblast by $\mathrm{H}_{2} \mathrm{O}_{2}$. Cells were divided into a control, $\mathrm{H}_{2} \mathrm{O}_{2}$ and NAC positive control. Each value is the mean \pm standard deviation of the results from six different plates $(n=6)$ and is representative of results from at least two different experiments. Statistical analysis was performed using the one-way ANOVA $(p<0.05)$

대조군의 cell viability를 기준(100\%)으로 하여 $\mathrm{H}_{2} \mathrm{O}_{2}$ 에 의해 산화적 스트레스가 유도된 세포의 cell viability는 79.7\%인 반 면, NAC 처리한 세포의 cell viability는 $87.0 \%$ 의 결과를 나타 내 산화적 손상을 억제 경향을 보였다. 하지만, $\mathrm{H}_{2} \mathrm{O}_{2}$ 와 $\mathrm{NAC}$ 를 처리한 근육세포 간의 유의적인 차이는 보이지 않았다.

한편, NFR 100, 250 및 $500 \mu \mathrm{g} / \mathrm{ml}$ 의 농도에서 세포 모두 산화적 손상에 의한 억제 효능은 나타나지 않았다(Fig. 3). 반 면, FR 및 MFR 시료에서는 각각 $100 \mu \mathrm{g} / \mathrm{ml}$ 의 농도에서 $\mathrm{H}_{2} \mathrm{O}_{2}$ 에 의한 산화적 손상을 일부 억제하는 것으로 나타났다(Fig. 4, 5).

반면, MFR 시료를 첨가한 근육세포의 경우, $\mathrm{H}_{2} \mathrm{O}_{2}$ 에 의해 손상된 근육세포의 cell viability가 추출물의 농도가 증가함에 따라 점차 증가하는 것으로 나타났다(Fig. 5). 즉, $\mathrm{H}_{2} \mathrm{O}_{2}$ 에 의 해 산화적 스트레스가 유도된 세포의 cell viability는 79.7\% (대조군 $100 \%$ 기준)인 반면, MFR 시료에서는 100,250 및 $500 \mu \mathrm{g} / \mathrm{m} \ell$ 의 농도에서 각각 $87.6,87.7$ 및 $98.9 \%$ 의 cell viability 를 나타내어, 유의적으로 높은 산화적 손상 억제 효과를 나타 내었다 $(p<0.05)$

이들의 결과로 비추어 볼 때, MFR 시료는 근육세포의 산화 


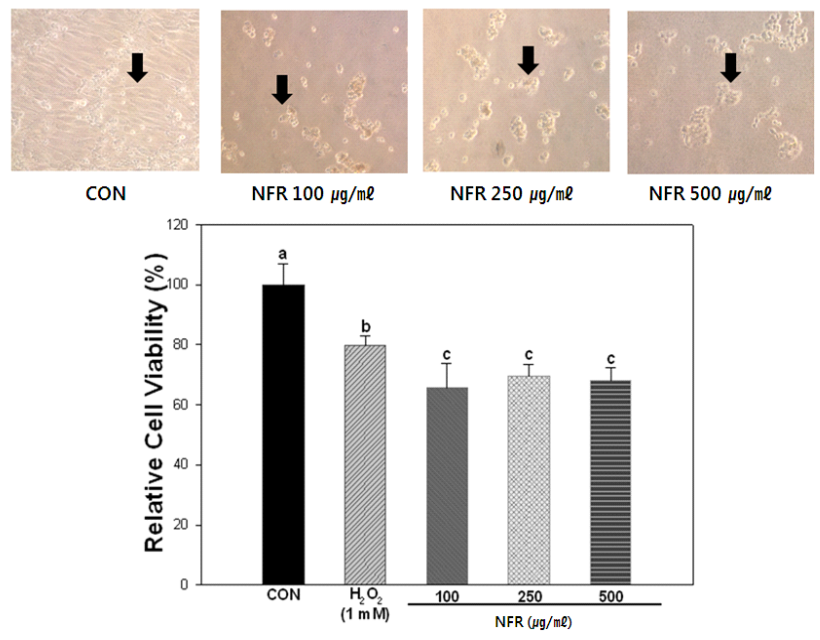

Fig. 3. Protective effect of non fermented Rhodiola sachalinensis(NFR) on cell viability of oxidative stressinduced $\mathrm{C2C12}$ myoblast by $\mathrm{H}_{2} \mathrm{O}_{2}$. Cells were divided into a control group and a sample group at concentration indicated. Each value is the mean \pm standard deviation of the results from six different plates $(n=6)$ and is representative of results from at least two different experiments. Statistical analysis was performed using the one-way $\operatorname{ANOVA}(p<0.05)$

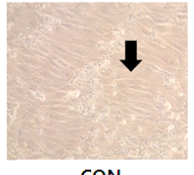

CON

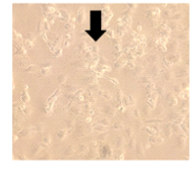

FR $100 \mu \mathrm{g} / \mathrm{m} \ell$

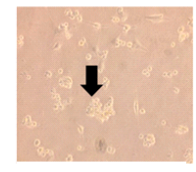

FR $250 \mu \mathrm{g} / \mathrm{m} \ell$
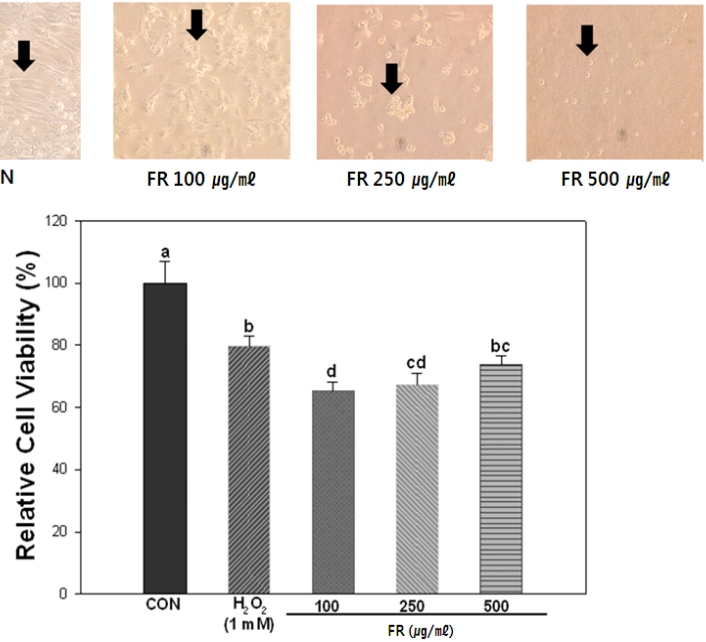

Fig. 4. Protective effect of ferments of hot-water extract from Rhodiola sachalinensis(FR) by Lactobacillus acidophillus and Bifidobacterium longum on cell viability of oxidative stress-induced $\mathrm{C2}_{2} \mathrm{C} 12$ myoblast by $\mathrm{H}_{2} \mathrm{O}_{2}$. Cells were divided into a control group and a sample group at concentration indicated. Each value is the mean \pm standard deviation of the results from six different plates $(\mathrm{n}=6)$ and is representative of results from at least two different experiments. Statistical analysis was performed using the one-way $\operatorname{ANOVA}(p<0.05)$
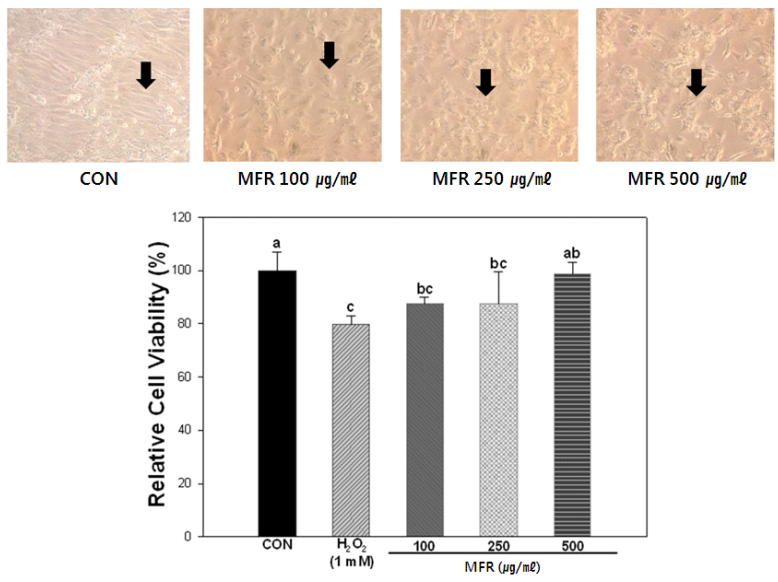

Fig. 5. Protective effect of ferments of hot-water extract mixture from Rhodiola sachalinensis and red ginseng (MFR) by Lactobacillus acidophillus and Bifidobacterium longum on cell viability of oxidative stress-induced $\mathrm{C} 2 \mathrm{C} 12$ myoblast by $\mathrm{H}_{2} \mathbf{O}_{2}$. Cell viability was measured by MTT assay. The exponentially growing cells were plated into 96-well micro plates at a density of $1 \times 10^{6}$ cells/well in DMEM/FBS medium and incubated for $24 \mathrm{~h}$ prior to treatment at $37^{\circ} \mathrm{C}$ in $5 \% \mathrm{CO}_{2}$. Cells were divided into a control group and a sample group at concentration indicated. Each value is the mean \pm standard deviation of the results from six different plates(n=6) and is representative of results from at least two different experiments. Statistical analysis was performed using the one-way $\operatorname{ANOVA}(p<0.05)$

적 손상으로부터 보호 효과를 나타내었으며, 이는 morphology 를 통해서도 확인되었기 때문에, 세포 내 항산화 효소의 유전 자 변화를 증가시켜 세포내 활성산소종(reactive oxygen speices) 을 감소시킬 것으로 추측되었다. 따라서, 항산화 효소 및 근 육세포 분화 관련 주요 유전자의 변화를 관찰해 보았다.

\section{3. 항산화 효소 및 근육세포 분화 관련 유전자 변화}

$\mathrm{C} 2 \mathrm{C} 12$ 세포내 산화적 손상 억제효과에 대한 작용기전을 알아보고자, $\mathrm{Cu} / \mathrm{Zn}-\mathrm{SOD}$ (copper/zinc superoxide dismutase), GPx (glutathione peroxidase)와 같은 항산화 효소 및 근육세포 분화 와 연관된 전사인자인 $\mathrm{Myo} \mathrm{D}$ 의 유전자 발현을 semi-quantitative RT-PCR로 분석하였다(Fig. 6). Myo D는 분화된 근육세포 내 에서 활성이 되는 유전자인데( $\mathrm{Kim}$ 등 2011), $\mathrm{H}_{2} \mathrm{O}_{2}$ 에 의해 산 화적 손상이 유도된 근육세포의 $\mathrm{Myo} \mathrm{D}$ 는 대조군에 비해 감 소하는 경향을 나타내었다. 또한, NFR 및 FR 시료를 처리한 근육세포의 $\mathrm{Myo} \mathrm{D}$ 는 대조군에 비해 현저한 감소치를 보였 다. 하지만, MFR 시료를 처리한 근육세포의 경우 $\mathrm{Myo} \mathrm{D}$ 의 유전자 발현은 $\mathrm{H}_{2} \mathrm{O}_{2}$ 에 의해 산화적 손상이 유도된 근육세포 

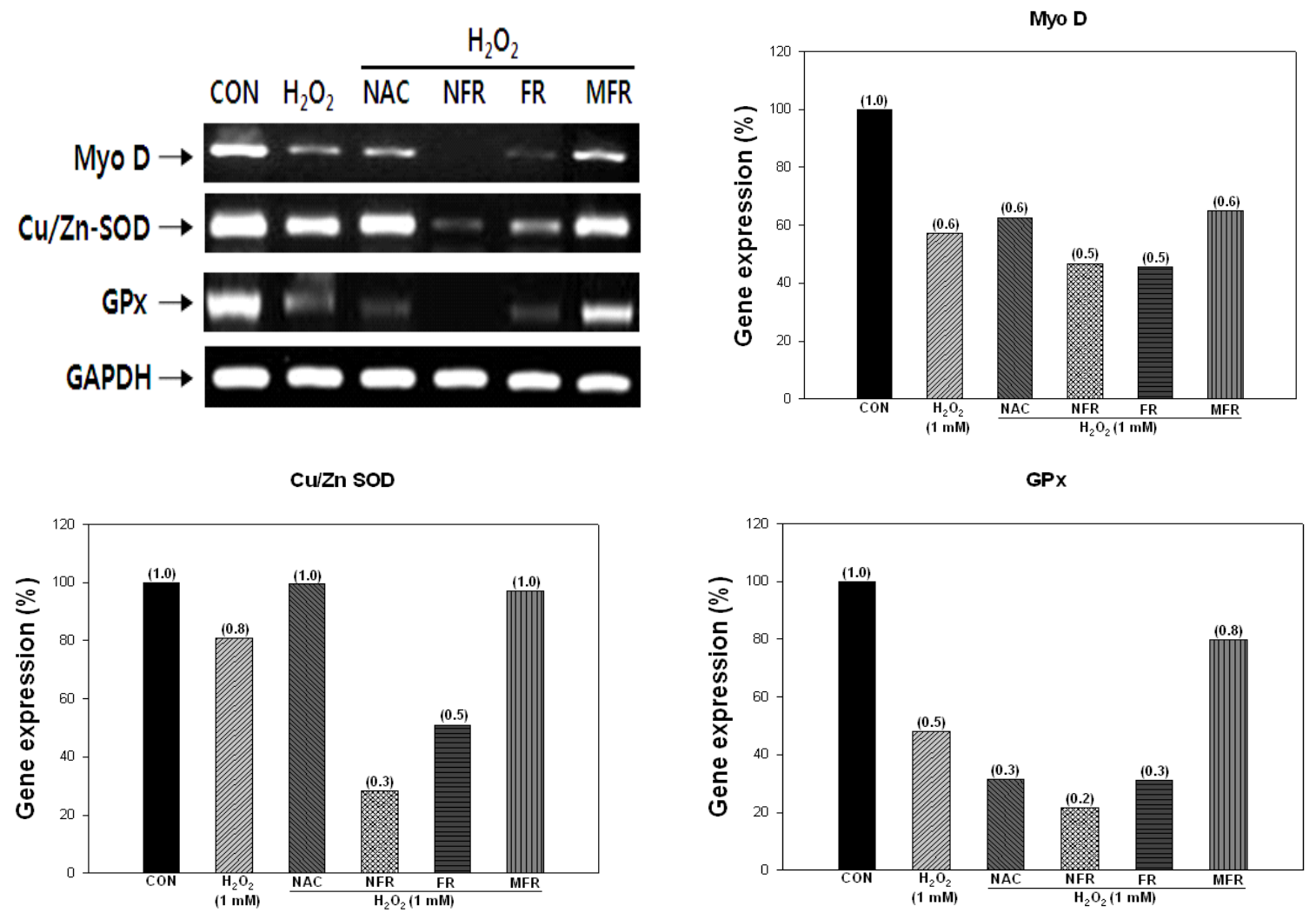

Fig. 6. Effect of various rhodiola samples on the mRNA expression of antioxidant enzymes and myoD. C2C12 cells were differentiated in the presence of $\mathrm{NAC}(1 \mathrm{mM})$ and various rhodiola samples $(250 \mu \mathrm{g} / \mathrm{m} \ell)$ throughout differentiation. On day 5 , total cellular RNA was extracted and subjected to RT-PCR. Antioxidant and myo D levels were quantified and normalized with GAPDH. The band intensities were measured using the Image J program

에서 Myo D 유전자 발현에 비해 증가한 것으로 나타났다. 또 한, 항산화 효소 중 $\mathrm{Cu} / \mathrm{Zn}-\mathrm{SOD}$ 및 $\mathrm{GPx}$ 의 유전자 발현도 $\mathrm{H}_{2} \mathrm{O}_{2}$ 에 의해 산화적 손상이 유도된 근육세포보다 큰 증가치를 나 타내었다. 이는 $\operatorname{Kim}$ 등(2012)의 논문에서 약용식물이 첨가된 발효홍삼을 투여한 당뇨병 유발 흰쥐의 SOD, CAT(catalase), $\mathrm{GPx}$ 및 GR(glutathione reductase)의 활성이 증가함으로써 자 유라디칼 생성 억제 및 활성 산소에 의한 산화적 손상으로부 터 생체를 보호하였다는 결과와 유사하였다.

이상의 결과로 볼 때, MFR 시료는 홍경천 추출물을 단독 으로 발효했을 시 나타나는 문제를 홍삼 추출물이 보완한 것 으로 사료되며, 이러한 이유로 NFR 및 FR 시료에 비해 산화 적 손상에 대한 억제 효과가 큰 것으로 나타났고, MFR 시료 를 처리한 근육세포 내 항산화 효소의 발현 조절을 통하여 산화적 손상을 억제한 것으로 판단되었다. 추후 세포 내 항산 화 효소의 활성 변화 및 동물 모델에서의 효능 평가를 통한 보다 구체적인 작용기전이 실시된다면 홍경천-홍삼 복합 발 효물(MFR)의 산화적 손상 억제에 대한 우수한 효능이 기대 된다.

\section{요 약}

본 연구에서는 피로 회복 또는 원기 회복에 효능이 있는 것으로 알려진 홍경천과 홍삼을 이용하여 홍경천-홍삼 복합 발효물의 산화적 손상 억제 효과를 평가하고자 $\mathrm{H}_{2} \mathrm{O}_{2}$ 로 산화 적 스트레스를 유도시킨 $\mathrm{C} 2 \mathrm{C} 12$ 근육세포에 홍경천-홍삼 복 합 발효물의 처리한 후, 세포의 morphology, cell viability 및 항산화 효소들의 유전자 발현 양상을 비교, 분석하였다. 홍경 천-홍삼 복합 발효물은 $\mathrm{C} 2 \mathrm{C} 12$ 근육세포의 cell viability를 유 의적으로 증가시켰으며, $\mathrm{Cu} / \mathrm{Zn}-\mathrm{SOD}, \mathrm{Mn}-\mathrm{SOD}$ 및 $\mathrm{GPx}$ 등과 같은 세포내 항산화 효소의 발현을 증가시킬 뿐만 아니라, 근 육세포 분화의 주요 전사인자인 Myo $\mathrm{D}$ 의 발현 또한 증가시 키는 것으로 나타났다. 이상의 결과로, 홍경천-홍삼 복합 발 효물은 세포내 항산화 효소 시스템을 증가시켜 외부로부터 의 산화적 손상에 대한 방어효능을 갖는 것으로 나타났으며, 향후 in vivo 시스템 이용한 추가적인 연구가 수행된다면, 홍 경천-홍삼 복합 발효물을 이용한 항피로 건강기능식품의 소 재개발이 가능할 것으로 판단된다. 


\section{References}

Alessio HM. 1993. Excercise-induced oxidative stress. Med Sci Sports Exerc 25:218-224

David LN, Michael M, Lehninger AL, Nelson DL, Cox MM. 1993. Principles of Biochemistry. Worth Publishers, Inc, United States

Dirks A, Leeuwenburgh C. 2002. Apoptosis in skeletal muscle with aging. Am J Physiol Regulatory Intergrative Comp Physiol 282:519-527

Fulder SJ. 1981. Ginseng and the hypothalamic-pituitary control of stress. Am J Chin Med 9:112-118

Halliwell B. 1989. Free radicals, reactive oxygen species, and human disease: a critical evaluation with special reference to atherosclerosis. Br J Exp Pathol 70:737-757

Hyun MS, Hur HM, Shin YS, Song BJ, Mun YJ, Woo WH. 2009. Comparison study of white ginseng, red ginseng, and fermented red ginseng on the protective effect of LPSinduced inflammation in RAW 264.7 cells. J Appl Biol Chem 52:21-27

Jackson MJ, O'Farrell SO. 1993. Free radical and muscle damage. Br Med Bull 49:630-641

Jenkins RR. 1993. Inbfluence of exercise clearance of oxidant stress products and loosely bound iron. Med Sci Sports Exer 23:213-217

Jennifer M, Sacheck, Jeffrey B. 2001. Blumberg role of vitamin E and oxidative stress in exercise. Nutrition 17:809-814

Kanupriya, Prasad D, Sai Ram M, Kumar R, Sawhney RC, Sharma SK, Ilavazhagan G, Kumar D, Banerjee PK. 2005. Cytoprotective and antioxidant activity of Rhodiola imbricata against tert-butyl hydroperoxide induced oxidative injury in U-937 human macrophages. Mol Cell Biochem 275:1-6

Kelly GS. 2001. Rhodiola rosea: a possible plant adaptogen. Altern Med Rev 6:293-302

Kim HJ, Lee SG, Park SJ, Yu MH, Lee EJ, Lee SP, Lee IS. 2012. Antioxidant effects of extracts from fermented red ginseng added with medicinal herbs in STZ-induced diabetic rats. Korean J Food Sci Technol 44:367-372

Kim HJ, Lee WJ. 2007. Effects of dietary polyphenol (-)epigallocatechin 3-gallate on the differentiation of mouse C2C12 myoblasts. Journal of Life Science 17:420-426

Kim KJ, Lee OH, Lee BY. 2011. Low-molecular-weight fucoidan regulates myogenic differentiation through the mitogen-activated protein kinase pathway in $\mathrm{C} 2 \mathrm{C} 12$ cells. British Journal of Nutrition 106:1836-1844

Lee YN. 1997. Flora of Korea. p.277. Seoul. Kyohak

Mook Jung I, Kim H, Fan W, Tezuka Y, Kadota S, Nishijo H, Jung MW. 2002. Neurorpotecitve effects of constituents of the oriental crude drugs, Rhodiola sacra, R. sachalinensis and Tokaku-joki-to, against beta-amyloid toxicity, oxidative stress and apoptosis. Biol Pharm Bul 25:1101-1104

Oh JK, Yoon JH, Shin YO, Kim BJ. 2010. Effect of Rhodiola rosea on aerobic capacity and anti-fatigue in elite long distance runners. The Korean Journal of Exercise Nutrition $14: 227-234$

Ryu SH, Kim SY, Jung HS, Sohn NW, Sohn YJ. 2008. Effects of Rhodiola rosea on anti-fatigue and hypothalarnic IEGs expressions of forced swimming rats. Kor J Herbology 23:9-19

Seo JE, Kim GH. 2012. Antioxidant activity and differentiation effect of Tataxacum mongolicum extracts against hyerogen peroxide-induced oxidative damage of MC3T3-E1 osteoblast cells. Korean J Food Cookery Sci 28:311-318

Stadman ER, Berlett BS. 1998. Reacitve oxgen-mediated protein oxidation in aging and disease. Drug Metabolism Reviews $30: 225-243$

Stangel M, Zettl UK, Mix E, Zielas J, Toyka KV, Hartung HP, Gold R. 1996. $\mathrm{H}_{2} \mathrm{O}_{2}$ and nitric oxide-mediated oxidative stress induce apoptosis in rat skeletal muscle myoblasts. $J$ Neuro Pathol Exp Neurol 55:36-43

Sung SK, Rhee YK, Cho CW, Lee YC, Kim YC, Hong HD. 2012. Physicochemical properties and antioxidative activity of lactic acid bacteria fermented Rhodiola sachalinensis using adsorption process. Korean J Food and Nutr 25:779786

Yoon BR, Lee YJ, Hong HD, Lee YC, Kim YC, Rhee YK, Kim KT, Lee OH. 2012. Inhibitory effects of Panax ginseng C. A. Mayer treated with high temperature and high pressure on oxidative stress. Korean J Food and Nutr 25:800-806

Yun JH. 2010. Effects of Chrysanthemum indicum L. extract in the activity and differentiation of osteoblastic MC3T3-E1 cells. Master's Thesis, Duksung Women's Uni. Seoul. Korea

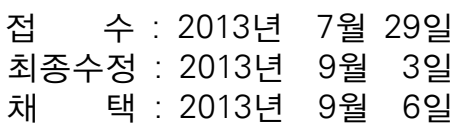

